\title{
Medicinal Plants Used for the Management of Rabies in Ethiopia - A Review
}

Asfaw Meresa*, Sileshi Degu, Ashenif Tadele, Bekesho Geleta, Hiwot Moges, Firehiwot Teka and Netsanet Fekadu

Directorate of Traditional and Modern Medicine Research, Ethiopian Public Health Institute, PO Box 1242, Addis Ababa, Ethiopia

\begin{abstract}
Background: Rabies is a deadly zoonotic viral disease. It is a major public-health problem which presents huge economic and health burdens in most parts of the developing world. The disease is difficult to treat once the clinical manifestations start to develop; the vaccines produced in mammalian neural tissues have the disadvantage of causing severe adverse reactions. This leads to the practice of traditional medicine for the control of rabies in most parts of Ethiopia for many years.
\end{abstract}

Objective: The aim of this review is to give an insight into some of the most commonly used folkloric plants and their method of preparation for the management of rabies.

Methods: Data for this review were generated from the published research findings on Ethiopian traditional medicinal plants on indifferent peer reviewed journals and proceedings using search words, Rabies in Ethiopia, medicinal plants, Ethno botanical studies and anti-rabies activity. Descriptive analysis was conducted using excel spreadsheets and the numbers of plants species and families were reported in frequency tables and figures.

Results: Results showed that a total of 199 plant species belonging to 47 families were used for the management of rabies. The most commonly used families were ephorbiacea stood first, followed by phytolaceae, cucurbitaceae, acanthracea, fabaceae and solianaceae. Phytolacadodecandra, Justicaschimperiana, Recinuscommunis, Brucea antidysenterica, Croton macrostachyus and Cucumis ficifolius were the most cited medicinal plant species utilized for the management of rabies. The most widely used plant part for the preparations of remedy were roots followed by leaves, used in solution form by using water as a most cited solvent.

Conclusions: This review indicated that there are many plants utilized for the management of rabies. Hence further research is recommended for ascertaining the efficacy, safety and quality of the claimed medicinal plants. There is also recommended to strengthen the documentation of the indigenous knowledge which contributes for the drug development used for the management of rabies.

Keywords: Rabies; Prevalence; Anti-rabies; Medicinal plants; Ethnobotany

\section{Introduction}

Rabies is a deadly zoonotic viral disease which causes encephalitis in all warm-blooded animals and humans [1]. The disease, which is a worldwide occurrence and endemic in most developing countries of African and Asian countries, is transmitted to humans mainly through physical contact (bites and scratches) with both domestic and wild infected animals [2]. Dogs which are the principal sources of the rabies virus significantly contribute to the widespread and transmission of the virus to humans as well as livestock $[1,3,4]$. Nearly $98 \%$ of human rabies occurs in countries with high populations of owned and strayed dogs [5]. Rabies is one of the viral diseases which could not be cured and reversed with existing rabies vaccines once clinical manifestations of the disease begin to surface [6].

Rabies is a major public-health problem which presents huge economic and health burdens in most parts of the developing world [7]. The disease is known to cause large number of deaths in humans and animals each year [3]. Several scientific reports indicate that rabies has accounted for an estimated death of nearly 55,000 people every year globally, with the majority of rabies fatalities estimated to occur in Asia and Africa [5]. People who are at risk of dying due to rabies in these continents are those living in the rural areas. An estimated 10 million people worldwide receive post-exposure treatment after being exposed to animals suspected of rabies [2]. Deaths due to rabies occur despite the availability of effective vaccines which can prevent the development of fatal rabies cases [3]. Besides its health burden, Rabies has greatly contributed to the economic loss of many rabies endemic developing countries of Asia and Africa as result of the high costs of human vaccine and rabies immunoglobulin (RIG) products, huge patient costs related to travel and income loss for post exposure prophylysis (PEP) as well as costs due to cattle loss. Secondly, the disease affects the open market of different countries, particularly those of rabies free countries by hampering the movement of animals between them [5]. An estimated of US $\$ 583.5$ million (most of which is due to the cost of post exposure prophylysis was annually spent in Africa and Asia due to rabies and the annual cost of livestock losses due to rabies is estimated to be US \$12.3 million in these continents. An estimated 10 million people worldwide receive post-exposure treatment after being exposed to animals suspected of rabies [2-4].

Deribe et al. [8] reported that about 996-14,694 cases of human rabies are estimated to occur in Ethiopia, mostly acquired through dog bites and the number of recorded human rabies cases has shown no apparent reduction for over twenty years in the country [8]. The

*Corresponding author: Asfaw Meresa, Directorate of Traditional and Modern Medicine Research, Ethiopian Public Health Institute, PO Box 1242, Addis Ababa, Ethiopia, Tel: 0112133499; E-mail: asfawmeresa03@gmail.com

Received February 03, 2017; Accepted February 17, 2017; Published February 27, 2017

Citation: Meresa A, Degu S, Tadele A, Geleta B, Moges H, et al. (2017) Medicinal Plants Used for the Management of Rabies in Ethiopia - A Review. Med Chem (Los Angeles) 7: 795-806. doi: 10.4172/2161-0444.1000431

Copyright: (C) 2017 Meresa A, et al. This is an open-access article distributed under the terms of the Creative Commons Attribution License, which permits unrestricted use, distribution, and reproduction in any medium, provided the original author and source are credited. 
high population density of dogs with poor management and limited vaccination, particularly in urban centers, greatly contributes to the high prevalence of the disease. Nearly 10, 000 people were estimated to die of rabies each year in Ethiopia. This makes it become one of the worst affected countries in the world $[1,4,9]$. Although it is difficult to estimate the prevalence and incidence of rabies at national level due to the absence of laboratory diagnosis and recorded data at different health facilities of the Country, a study by Ali et al. [7] uncovered that there was high occurrence of rabies in and around Addis Ababa due to the poor management of owned dogs and the presence of high population of unvaccinated stray dogs [7].

Ethiopia has remained behind in rabies control effort due to various socioeconomic factors and low understanding of the actual trend of the disease despite its effectiveness in rabies prevention than reliance on post exposure human treatments [7]. Rabies vaccines produced in mammalian neural tissues have the disadvantage of causing severe adverse reactions, at a rate estimated as $0.3-0.8$ per thousand treated patients [10]. Similarly, the cell culture rabies vaccines are expensive and not readily available to individuals living in developing countries where rabies is endemic in dogs [11]. The high costs of tissue culture vaccine and inertia have been the main barrier to the replacement of Fermi type vaccine [10]. The practice of traditional medicine for the control of rabies in most parts of Ethiopia is based on the use of plant medicines for many years. Several traditional herbs have been formulated by traditional healers to treat human and animal rabies [12].

\section{Materials and Methods}

The ethno-botanical information was collected from different ethno botanical publications by graduate students over the past couple of decades, the relevant ethno botanical MSC theses as well as publications; research reports other botanical sources as well as databases were also reviewed. Various on-line sources including Google Scholar were browsed using some important key terms such as Rabies in Ethiopia, medicinal plants, Ethno-botanical studies. The scientific names were checked and confirmed with volumes of the Flora of Ethiopia and Eritrea. Appropriate data collection format was prepared to tabulate scientific, family and local names of species along with plant parts used, diseases treated and preparation of each species. The information was entered in Excel spread. The collected data were analyzed using descriptive statistics to evaluate the percentage and frequency of different aspects such as, diversity of plants, applications, method of preparation and plant parts used. The results were presented with figures and tables.

\section{Results}

\section{Diversity plant resources in the study area}

A total of 199 species belonging to 47 families were included in this review. This finding is a good indicator for the presence of considerable diversity of plant species for the management of rabies in Ethiopia. In terms of family distribution, Ephorbiacea stood first, followed by phytolaceae, cucurbitaceae, acanthracea, Fabaceae and solianaceae (Figure 1).

\section{Plant species most frequently reported}

Phytolacadodecandra, Justicaschimperiana, Recinuscommunis, Brucea antidysenterica, Croton macrostachyus, Cucumis ficifolius, Salix subserrata, Calpurnia aurea and Euphorbia abyssinica were mentioned at $21,14,10,7,7,7,6,5$ and 5 sites, respectively for the treatment of rabies (Table 1).

\section{Conditions of preparation, solvents and additives of herbal remedies}

As evident on Figure 2, herbal remedies are prepared using fresh material, dried form and some cases either fresh or dried form of the plant parts are utilized. Some of the remedies are taken with different additives and solvents; the most common solvent used is water is water followed by milk and local alcohol. Commonly used additives to prepare the medicinal plant material include butter, honey, milk, and Citrus juice.

\section{Plant parts, method of preparation and applications}

Regarding the preparation of medicinal plants for rabies treatment, various methods of preparation were utilized. The plant remedy preparations consisted mostly of solutions, mixture of powders, infusions, powdering, chopping, decoction, and burning. The prepared traditional medicines were applied in a number of methods; orally drinking or taking with food, directly apply on the affected area (either through the fresh leaf, latex, powder or oil); rubbing (with fresh leaf,

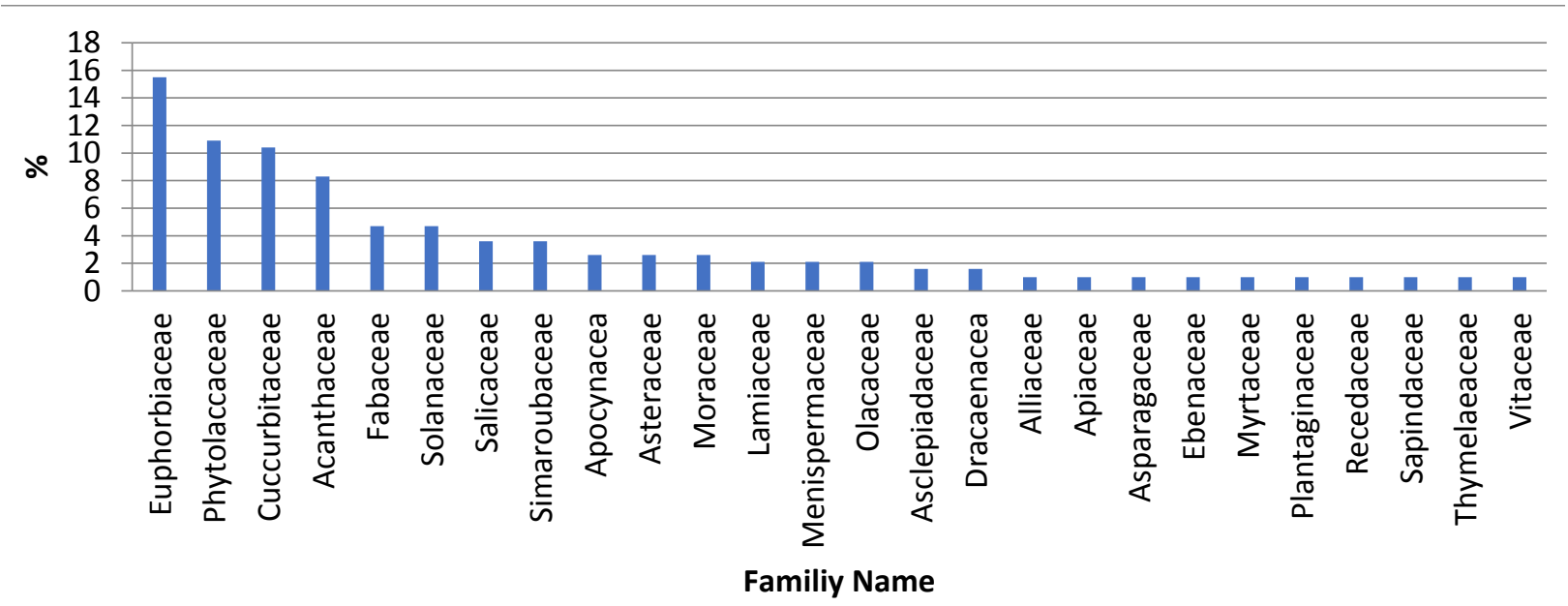

Figure 1: Diversity of Plant species for the management of rabies. 
powder, latex or ash of the burned part), squeezing on the affected area, or painting applied on the affected area from the herbal preparations (Table 2). The most widely used plant part for the preparations of remedy were root followed by leaves, which accounted for 41.51 and $29.25 \%$ (Figure 3).

Generally, there are many medicinal plants that are claimed to be used for the management of rabies. As shown in different sources of references (Table 2), however, the same plant species have been utilized in most areas of the country although there are slight variations in their ethno botanical application.

\begin{tabular}{|l|c|c|}
\hline Medicinal plant name & Number of reports & Percent \\
\hline Phytolaca dodecandra & 21 & 10.6 \\
\hline Justica schimperiana & 14 & 7.0 \\
\hline Ricinus communis & 10 & 5.0 \\
\hline Brucea antidysenterica & 7 & 3.5 \\
\hline Croton macrostachyus & 7 & 3.5 \\
\hline Cucumis ficifolius & 7 & 3.5 \\
\hline Salix subserrata & 6 & 3.0 \\
\hline Calpurnia aurea & 5 & 2.5 \\
\hline Euphorbia abyssinica & 5 & 2.5 \\
\hline Artemisia abyssinica & 3 & 1.5 \\
\hline Clucia lanceolata & 3 & 1.5 \\
\hline Daturastramonium & 3 & 1.5 \\
\hline Dorstenia barnimiana & 3 & 1.5 \\
\hline Dracaena steudneri & 3 & 1.5 \\
\hline Lagenaria siceraria & 3 & 1.5 \\
\hline Momordica foetida & 3 & 1.5 \\
\hline Solanum gigantum & 3 & 1.5 \\
\hline Stephania abyssinica & 3 & \\
\hline Total & 3 & 1.0 \\
\hline & 3 & \\
\hline
\end{tabular}

Table 1: Plant species reported for the management of rabies in Ethiopia.

\section{Discussion}

Ethno botanical investigations have been found to offer important clues in the identification and development of traditionally used medicinal plants in to modern drugs. Phytolaccadodecandra L, Justicaschimperiana, Ricinuscommunis, Croton macrostachyus Hochst. Ex, Cucumisficifolius, Brucea antidysenterica, Euphorbia abyssinica J. F. Gmel, Salix subserrata are the top five medicinal plants being utilized for the management of rabies by the Ethiopian traditional health care system.

This folk medicinal claim is also further supported with against anti-rabies activity; among the listed medicinal plants, the anti-rabies activity of only three medicinal plants had been scientifically evaluated in Ethiopia. These plants include PhytolaccadodecandraL, Salix substrata and Silene macroselen. A study conducted on mice to evaluate the anti-rabies activity of the hydroethanolic extract of roots and leaves of Phytolacca dodecandra revealed that $80 \%$ ethanol macerated extract of both plant parts at the doses of $300,600 \mathrm{mg} / \mathrm{kg}$ failed to display an increase in survival period of mice challenged with the rabies virus (CVS-11) compared with negative control. However, the leaf extract at $1000 \mathrm{mg} / \mathrm{kg}$ significantly $(\mathrm{P}>0.05)$ increased the survival period of mice compared to negative controls.

Deressa et al. [12] also conducted a study on the evaluation of the efficacy of the crude extracts of Salix subserrata and Silene macroselen for the treatment of rabies in Ethiopia. The result demonstrated that the chloroform and methanol $80 \%$ extracts of the leaf of Salix subserrata and the chloroform and aqueous extract of the root of the same plant were found to increase the survival time of mice significantly [10]. These efficacy studies support the traditional use of the medicinal plants. However, deeper scientific investigations on the active ingredients, efficacy as well as safety profiles are necessary not only on these plants but also on the other medicinal plants which are not studied scientifically. These are the phytochemistry, efficacy and toxicity studies of commonly used Ethiopian medicinal plants for treatment of rabies virus.

\section{Salix subserrata}

Family: Salicaceae

Local name: Aleltu (Amharic) Wonzadmik/akaya

\subsection{0}

\subsection{0}

40.00

우 30.00

20.00

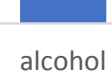

coffee
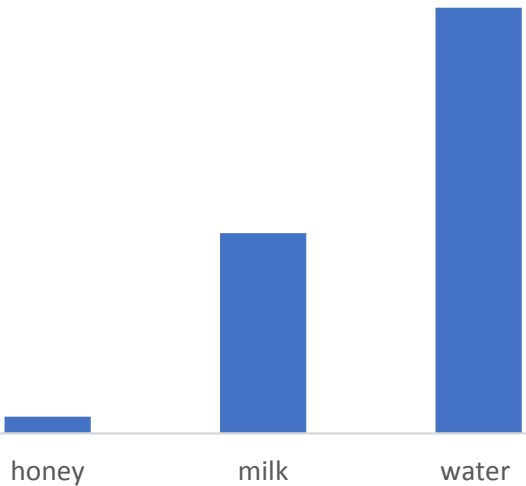

Vehicles for treatment preparations

Figure 2: Common solvents and additives used for the administration of medicinal plant parts for the management of rabies in Ethiopia. 
Citation: Meresa A, Degu S, Tadele A, Geleta B, Moges H, et al. (2017) Medicinal Plants Used for the Management of Rabies in Ethiopia - A Review. Med Chem (Los Angeles) 7: 795-806. doi: 10.4172/2161-0444.1000431

\begin{tabular}{|c|c|c|c|c|c|c|c|c|}
\hline S No & Scientific name & Family name & Local name & $\begin{array}{l}\text { Part (s) } \\
\text { used }\end{array}$ & Method of preparation & $\begin{array}{l}\text { Route of } \\
\text { administration }\end{array}$ & $\begin{array}{l}\text { Treatment } \\
\text { for: }\end{array}$ & References \\
\hline 1. & Daturastramonium L. & Solanaceae & $\begin{array}{l}\text { Machareqqa [ka] } \\
\text { Banjii [O] }\end{array}$ & Leaf & $\begin{array}{l}\text { Crushed and homogenized leaves } \\
\text { drunk with water }\end{array}$ & Oral & Human & {$[1,13,14]$} \\
\hline 2. & $\begin{array}{l}\text { Justitia schimperana } \\
\text { (Hochst. ex Nees) T. } \\
\text { anders }\end{array}$ & Acanthaceae & $\begin{array}{l}\text { Gulbanna [ka] } \\
\text { Dhumuga (O] } \\
\text { Smiza }[A]\end{array}$ & $\begin{array}{l}\text { Buds } \\
\text { Root } \\
\text { Leaf }\end{array}$ & $\begin{array}{l}\text { Roots and leaves are pounded } \\
\text { together and mixed with water and } \\
\text { Salix mucronata leaf and given } \\
\text { orally for human and animals in } \\
\text { the morning before food }\end{array}$ & Oral & Both & {$[1,13-27]$} \\
\hline 3. & Cucumisficifolius & & Yemidrembuay & roots & $\begin{array}{l}\text { Powder of roots eaten with } \\
\text { 'Teffkita/ Crushed fresh root with } \\
\text { water fermented for } 3 \text { days is } \\
\text { taken with honey early morning } \\
\text { before breakfast orally until cure }\end{array}$ & Oral & Both & {$[1,18,27-30,58]$} \\
\hline 4. & Dorsteniabarnimiana & & $\begin{array}{l}\text { Work Bemeda } \\
{[\mathrm{A}]}\end{array}$ & Root & $\begin{array}{l}\text { Powder of roots taken with } \\
\text { skimmed milk or noug orally in the } \\
\text { morning for seven days }\end{array}$ & Oral & Human & {$[1,30,31]$} \\
\hline 5. & Gnidiaglauca & & Beto $[\mathrm{A}]$ & Root & $\begin{array}{l}\text { Powder of roots mixed with } \\
\text { skimmed milk and taken orally for } \\
\text { seven days }\end{array}$ & & Human & {$[1,30]$} \\
\hline 6. & Phytolaccadodecandra & Phytolaceae & $\begin{array}{l}\text { Endod, Shibti, } \\
\text { Haranje, Handode }\end{array}$ & $\begin{array}{l}\text { Root } \\
\text { Leaf }\end{array}$ & $\begin{array}{l}\text { Powder of roots or leaves mixed } \\
\text { with water or domestic alcohol } \\
\text { and given orally to humans and } \\
\text { animals }\end{array}$ & Oral & Both & $\begin{array}{l}{[1,16,18,21-24,26-} \\
28,30,32,41]\end{array}$ \\
\hline 7. & Salix subserrata & & Aleltu[O] & leaf & $\begin{array}{l}\text { Leaves from the tree given orally } \\
\text { Leaves are pounded and dried, } \\
\text { and then mixed with milk }\end{array}$ & & Human & {$[1,19,34,42-44]$} \\
\hline 8. & $\begin{array}{l}\text { Croton macrostachyus } \\
\text { Del. }\end{array}$ & Euphorbiaceae & Makkanisa [O] & $\begin{array}{l}\text { Root } \\
\text { Bark } \\
\text { Leaf }\end{array}$ & $\begin{array}{l}\text { Pound the fresh root, add water } \\
\text { and filter then administered orally } \\
\text { for } 3 \text { days (dog) and } 7 \text { days (other } \\
\text { animals) and apply topically; The } \\
\text { Bark of Croton macrostachyus is } \\
\text { dried, powdered and mixed with } \\
\text { water one coffee cup is given for } \\
\text { human and } 1 \text { bottle is given to } \\
\text { castles and } 6 \text { bottles is given to } \\
\text { camel once a day for } 3\end{array}$ & Oral & Both & {$[15,16,28,40,41,46]$} \\
\hline 9. & Silenemacroselen & & Wegert[O] & Root & Root from herbs given orally & Oral & Human & {$[1,12]$} \\
\hline 10. & Bruceaantidysentrica & Simaroubaceae & Qomonyoo [O] & $\begin{array}{l}\text { FruitLeaf } \\
\text { Root }\end{array}$ & $\begin{array}{l}\text { Squeezed and baked with teff } \\
\text { flour andgiven for } 3 \text { days [together } \\
\text { with Croton macrostachyus and } \\
\text { Rumexnervosus]. }\end{array}$ & Oral & $\begin{array}{l}\text { Live stock } \\
\text { Both }\end{array}$ & {$[16,18,20,22,27,38]$} \\
\hline 11. & $\begin{array}{l}\text { Euphorbia abyssinica } \\
\text { J. F. Gmel }\end{array}$ & Euphorbiaceae & $\begin{array}{l}\text { Qulqwal } \\
{[\mathrm{A}]}\end{array}$ & $\begin{array}{l}\text { Root } \\
\text { Latex } \\
\text { Leaf }\end{array}$ & $\begin{array}{l}\text { One spoon root powder mixed } \\
\text { with a cup of fresh milk. Give for } \\
\text { dog or Powder of roots or leaves } \\
\text { mixed with water and taken orally }\end{array}$ & Oral & both & {$[1,17,24,30,32,47]$} \\
\hline 12. & Ricinus- communis & Euphorbiaceae & Qoobboo[O] & Leaf root & $\begin{array}{l}\text { Fresh leaves crushed and mixed } \\
\text { with water and taken one cup of } \\
\text { tea for } 3 \text { consecutive days }\end{array}$ & & Human & $\begin{array}{l}{[15,18-20,} \\
22,27,36,42,46]\end{array}$ \\
\hline 13. & $\begin{array}{l}\text { Calpurnia aurea (Ait.) } \\
\text { Benth., }\end{array}$ & Fabaceae, (AE & Digita [A] & $\begin{array}{l}\text { Leaf } \\
\text { Fruit } \\
\text { Seed } \\
\text { Root }\end{array}$ & $\begin{array}{l}\text { Fresh or dried leaf, fruit and } \\
\text { seeds crushed, mixed with food } \\
\text { and given to dogs }\end{array}$ & $\begin{array}{l}\text { Oral } \\
{[L]}\end{array}$ & Livestock & {$[15,17,29,40,48]$} \\
\hline 14. & $\begin{array}{l}\text { Artemisiaabyssinica } \\
\text { Sch., Bip. ex A.Rich. }\end{array}$ & Asteraceae & $\begin{array}{l}\text { Qoddo }[\mathrm{O}] \\
\text { Chikugn[A] }\end{array}$ & Leaf & $\begin{array}{l}\text { Leaf is ground in small water and } \\
\text { given to the victim every morning } \\
\text { for } 3 \text { days in small 'areqe' glass } \\
\text { (Kenneeraa) }\end{array}$ & oral & both & {$[25,28]$} \\
\hline 15. & Momordicafoetida & Cucurbitaceae & $\begin{array}{l}\text { Saaroobofaa } \\
{[\mathrm{O}]}\end{array}$ & $\begin{array}{l}\text { Root } \\
\text { Leaf } \\
\text { stem }\end{array}$ & $\begin{array}{l}\text { Pounding the roots, making } \\
\text { Solution \& drinking one coffee cup } \\
\text { at once. }\end{array}$ & Oral, nasal & Human & {$[15,36]$} \\
\hline 16. & Zehneriascabra & Cuccurbitaceae & $\begin{array}{l}\text { Korisinbira[O] } \\
\text { Hiddareeffaa [o] }\end{array}$ & $\begin{array}{l}\text { Root } \\
\text { Leaf }\end{array}$ & Pounded roots taken orally & Oral & human & {$[1,18]$} \\
\hline
\end{tabular}


Citation: Meresa A, Degu S, Tadele A, Geleta B, Moges H, et al. (2017) Medicinal Plants Used for the Management of Rabies in Ethiopia - A Review. Med Chem (Los Angeles) 7: 795-806. doi: 10.4172/2161-0444.1000431

\begin{tabular}{|c|c|c|c|c|c|c|c|c|}
\hline 17. & $\begin{array}{l}\text { Stephaniaabyssinica } \\
\text { (Dillon\&A.Rich }\end{array}$ & Menispermaceae & $\begin{array}{l}\text { HiddaHantutaa[O] } \\
\text { Yet areg }[\mathrm{A}]\end{array}$ & $\begin{array}{l}\text { Root } \\
\text { Leaf }\end{array}$ & $\begin{array}{l}\text { Dry root of Stephaniaabyssinica } \\
\text { will be powdered and backed } \\
\text { with teff flour and given to cattle. } \\
\text { A crushed of leaf and root are } \\
\text { soaked in honey for one day, } \\
\text { decanted and one cup of juices is } \\
\text { taken orally. }\end{array}$ & $\begin{array}{l}\text { Oral } \\
{[L]}\end{array}$ & Both & {$[16,24,32,38]$} \\
\hline 18. & $\begin{array}{l}\text { Lagenariasiceraria } \\
\text { (Molina) Standl }\end{array}$ & Cucurbitaceae & Qel $[A]$ & Fruit & $\begin{array}{l}\text { The fruit of Lagenariasiceraria } \\
\text { and Calpurnaaurea are ground } \\
\text { together and backed with powder } \\
\text { of Teff given to the cattle as a } \\
\text { breakfast for } 3 \text { days (given to } \\
\text { dogs. }\end{array}$ & Oral & L ivestock & {$[28,49]$} \\
\hline 19. & Clucia lance olata & Euphorbiaceae & Uleefoonii[o] & root & Fresh leaves hold in teeth & oral & Both & {$[18,22,27]$} \\
\hline 20. & $\begin{array}{l}\text { Olea } \\
\text { eureapa }\end{array}$ & Oleaceae & Ejersa [o] & Leaf & $\begin{array}{l}\text { Root crushed and taken with } \\
\text { coffee (Rabies) }\end{array}$ & Inhalation & human & {$[18,22]$} \\
\hline 21. & $\begin{array}{l}\text { Solanumgigantum } \\
\text { Jacq. }\end{array}$ & Solanceae & Hiddii saree [o] & Root & $\begin{array}{l}\text { Root crushed and taken with } \\
\text { coffee }\end{array}$ & Oral & Human & {$[22,46]$} \\
\hline 22. & Allium sativumL & Alliaceae & Nechshinkurt $[\mathrm{A}]$ & Bulb & $\begin{array}{l}\text { Eat the part or } \\
\text { Whole bulb directly }\end{array}$ & Oral & Human & {$[23,50]$} \\
\hline 23. & $\begin{array}{l}\text { Acokantheraschimperi } \\
\text { (DC) Benth }\end{array}$ & Apocynaceae & Merenze[A] & Root & $\begin{array}{l}\text { The root of } \\
\text { Acokantheraschimperiwith the } \\
\text { root of Cucumisficifolius pounded } \\
\text { together mixed with water and } 1 \\
\text { litter is given to cattle once a day } \\
\text { for } 3 \text { days. }\end{array}$ & Oral & $\begin{array}{l}\text { Live } \\
\text { stock }\end{array}$ & {$[28,49]$} \\
\hline 24. & $\begin{array}{l}\text { Dregeaschimperi(Decne.) } \\
\text { Bullock }\end{array}$ & Asclepiadaceae & $\begin{array}{l}\text { Shanqoq } \\
{[T]}\end{array}$ & $\begin{array}{l}\text { Leaf } \\
\text { Fruit }\end{array}$ & $\begin{array}{l}\text { Crush and drink the fluid Crushed } \\
\text { And to be drunk }\end{array}$ & Oral & Both & {$[50,51]$} \\
\hline 25. & $\begin{array}{l}\text { Dracaena steudneri } \\
\text { Engl. }\end{array}$ & Dracaenacea & Atsu [O] & $\begin{array}{l}\text { Bark } \\
\text { Leaf }\end{array}$ & Leaves taken orally & & Both & {$[1,15,27,32]$} \\
\hline 26. & Euphorbia tirucalli L., & Euphorbiaceae & $\begin{array}{l}\text { Kinchib[A] Tsedo } \\
\text { (M) }\end{array}$ & $\begin{array}{l}\text { Latex } \\
\text { Root }\end{array}$ & $\begin{array}{l}\text { Latex mixed with bean powder } \\
\text { and given to eat after food }\end{array}$ & $\begin{array}{l}\text { Oral } \\
\text { [] }\end{array}$ & Both & {$[16,52]$} \\
\hline 27. & Euphorbia ampliphylla & Euphorbiaceae & Qulquale $[\mathrm{A}]$ & Sap/latex & $\begin{array}{l}\text { The drop of latex is collected, } \\
\text { mixed with "teff" powdered and } \\
\text { backed and then eaten } 1 / 3 \text { of it }\end{array}$ & Oral & Human & {$[35,40]$} \\
\hline 28. & Eucleanatalensis $L$ & Ebenaceae & Kuliaw [T] & & Not stated & & Both & {$[53,54]$} \\
\hline 29. & RumexnervoususVahl.: & Polygonacea & Dhangaggo o [o] & Root & $\begin{array}{l}\text { The root of Rumexnervosus } \\
\text { together with that of } \\
\text { Phytolaccadodecandra, } \\
\text { Bruceaantidysenterica, Croton } \\
\text { macrostachyus will be pounded } \\
\text { together } 1 \text { teaspoon will be drunk } \\
\text { with coffee }\end{array}$ & Oral & Human & {$[16]$} \\
\hline 30. & $\begin{array}{l}\text { Scandoxusmultiflorus } \\
\text { (Martyn) Raf.: }\end{array}$ & Amaryllidace ae & $\begin{array}{l}\text { QulubiWarabesa } \\
\text { [o] }\end{array}$ & Bulb & $\begin{array}{l}\text { Bulb of Scandoxusmultiflorus will } \\
\text { be pounded with bark of Croton } \\
\text { macrostachyus and put in cold } \\
\text { water for 1-night then by filtering } \\
\text { one cup given to human }\end{array}$ & oral & Human & {$[16]$} \\
\hline 31. & CappariscartilagineaDecne.: & Capparidaceae & Goraa [o] & Root & $\begin{array}{l}\text { Root of Cappariscartilaginea } \\
\text { together with that of } \\
\text { Phytolaccadodecandra, } \\
\text { Bruceaantidysenterica and Croton } \\
\text { macrostachyus will be pounded } \\
\text { and given to cattle }\end{array}$ & Oral & Livestock & {$[16]$} \\
\hline 32. & HypericumrevolutumVahl: & Guttifera & Hinedhe [o] & $\begin{array}{l}\text { Root } \\
\text { Leaf }\end{array}$ & $\begin{array}{l}\text { The root and leaf of } \\
\text { Hypericumrevolutum together } \\
\text { with roots of Rumexnervosus } \\
\text { and Phytolaccadodecandra, } \\
\text { Bruceaantidysenterica, leaf and } \\
\text { bark of Croton macrostachyus will } \\
\text { be pounded together mixed with } \\
\text { water and given to cattle. }\end{array}$ & $\begin{array}{l}\text { Oral } \\
{[L]}\end{array}$ & Livestock & {$[16]$} \\
\hline 33. & Mikaniacapensis DC.: & Asteraceae & HiddaReeffa [o] & Root & $\begin{array}{l}\text { The root of Mikaniacapensis and } \\
\text { Cucumisficifolius will be powdered } \\
\text { together mixed with water given } \\
\text { to cattle. }\end{array}$ & Oral & Livestock & {$[16]$} \\
\hline
\end{tabular}


Citation: Meresa A, Degu S, Tadele A, Geleta B, Moges H, et al. (2017) Medicinal Plants Used for the Management of Rabies in Ethiopia - A Review. Med Chem (Los Angeles) 7: 795-806. doi: 10.4172/2161-0444.1000431

\begin{tabular}{|c|c|c|c|c|c|c|c|c|}
\hline 34. & $\begin{array}{l}\text { Maytenussenegalensis } \\
\text { (Lam.) Exell, }\end{array}$ & Celastraceae, & GeramAtat $[A]$ & Leaf & $\begin{array}{l}\text { Fresh young leaf is crushed and } \\
\text { applied topically }\end{array}$ & Topical & Human & [17] \\
\hline 35. & Rhynchosiaelegans A. Rich. & Fabaceae, & TeroAreg $[\mathrm{A}]$ & Leaf & $\begin{array}{l}\text { Fresh or dried leaf paste or } \\
\text { powder mixed with little water } \\
\text { is given orally to human and } \\
\text { livestock }\end{array}$ & Oral & Both & [17] \\
\hline 36. & Salix mucronataThunb., & Salicaceae, & Achaya $[\mathrm{A}]$ & Leaf & $\begin{array}{l}\text { Fresh leaf mixed with } \\
\text { Justiciaschimperiana leaf and } \\
\text { squeezed juice is given orally } \\
\text { before food to human and } \\
\text { livestock }\end{array}$ & $\begin{array}{l}\text { Oral } \\
{[B]}\end{array}$ & Both & {$[17]$} \\
\hline 37. & Carissa edulisVahl. & Apocynaceae & Agamsa (O) & Root & $\begin{array}{l}\text { The root is powdered and mixed } \\
\text { with food. }\end{array}$ & oral & Human & [19] \\
\hline 38. & $\begin{array}{l}\text { Carissa spinarum } \\
\text { L. }\end{array}$ & Apocynaceae & Agamsa[O] & $\begin{array}{l}\text { Root } \\
\text {,bark }\end{array}$ & & & Human & [29] \\
\hline 39. & $\begin{array}{l}\text { Lagenariaabyssinica } \\
\text { (hook.f.) C.Jeffre }\end{array}$ & Cucurbitaceae & Buqesetena $(\mathrm{O})$ & Root & Powdered root is mixed with food. & Oral & Human & [19] \\
\hline 40. & AntiaristoxicariaLesch. & Moraceae & Dimbicho [O] & Bark & $\begin{array}{l}\text { Dry/fresh stem bark is pounded } \\
\text { and powdered then mixed with } \\
\text { milk and given orally }\end{array}$ & & Human & [39] \\
\hline 41. & Combretumcollinum & Combretaceae & Abalo $[A]$ & Seeds & $\begin{array}{l}\text { The seed of Combretumcollinum } \\
\text { with seed of Solanumdasyphyllum } \\
\text { are crushed together powdered, } \\
\text { mixed with "tella" and drunk for } \\
3 \text { days }\end{array}$ & Oral & Human & [35] \\
\hline 42. & Otostegiaintegrifolia & Lamiaceae & $\begin{array}{l}\text { Tungut } \\
{[\mathrm{A}]}\end{array}$ & Leaf & $\begin{array}{l}\text { The leaf of Otostegiaintegrifolia } \\
\text { is pounded mixed with milk and } \\
\text { drunk }\end{array}$ & Oral & Human & [35] \\
\hline 43. & Ficus sp. & Moraceae & $\begin{array}{l}\text { Warka } \\
{[\text { A] }}\end{array}$ & $\begin{array}{l}\text { Stem } \\
\text { bark, } \\
\text { latex }\end{array}$ & + Phytolaccadodecandra & Oral & Human & [40] \\
\hline 44. & Jatropha curcas $L$ & Euphorbiaceae & Yesudan-gulo $[\mathrm{A}]$ & Seed & Not specified & Oral & Human & [40] \\
\hline 45. & $\begin{array}{l}\text { CissampelosmucronataA. } \\
\text { Rich. }\end{array}$ & Menispermaceae & Balari (M & Root & Not specified & Oral & Livestock & [52] \\
\hline 46. & $\begin{array}{l}\text { Clausenaanisata } \\
\text { (Wild.) Benth }\end{array}$ & Rutaceae & $\begin{array}{l}\text { Ulmaayii } \\
\text { [o] }\end{array}$ & Bark & $\begin{array}{l}\text { Bark of Clausenaanisata, leaves } \\
\text { of Sidarhombifolia, root of } \\
\text { Cucumisficifolius, bark root of } \\
\text { Bruceaantidysentrica powdered } \\
\text { together and mixed in milk then } \\
\text { drunk a cup of tea for three days } \\
\text { in order to get cured from Rabies } \\
\text { disease }\end{array}$ & Oral & Human & [46] \\
\hline 47. & $\begin{array}{l}\text { Crotalaria } \\
\text { spinosaHochst. ex. } \\
\text { Benth. }\end{array}$ & Fabaceae & $\begin{array}{l}\text { Shumburaagugee } \\
\text { [0] }\end{array}$ & Root & $\begin{array}{l}\text { Root crushed, mixed with water } \\
\text { and drunk }\end{array}$ & Oral & & [46] \\
\hline 48. & Argemonemexicana $L$. & Papaveraceae & Yahyaeshoh[A] & Root & Crush then give with water & Not stated & Both & [24] \\
\hline 49. & DiplolophiumafricanumTurcz & Apiaceae & $\begin{array}{l}\text { Zegerawta } \\
{[\mathrm{A}]}\end{array}$ & Root & Pound and give with water & Not stated & Both & [24] \\
\hline 50. & $\begin{array}{l}\text { DipsacuspinnatifidusSteud. } \\
\text { ex A. Rich. }\end{array}$ & Dipsacaceae & $\begin{array}{l}\text { Ferezeng/kelem } \\
{[\mathrm{A}]}\end{array}$ & Leaf & Pound and give with water [b] & Not stated & Both & [24] \\
\hline 51. & Millettiaferruginea & & & $\begin{array}{l}\text { Young } \\
\text { stem }\end{array}$ & $\begin{array}{l}\text { Heat the right side of cattle with } \\
\text { stick of Millettiaerrugineay and } \\
\text { Bruceaantidysenterica for about } \\
\text { seven days }\end{array}$ & Dermal & $\begin{array}{l}\text { Live } \\
\text { stock }\end{array}$ & [24] \\
\hline 52. & $\begin{array}{l}\text { Cyphostemmaadenocaula } \\
\text { (A.Rich.) (Vitacea }\end{array}$ & Vitaceae & $\begin{array}{l}\text { Asserkush } \\
{[\text { A] }}\end{array}$ & Root & $\begin{array}{l}\text { Root boiled with milk, filtered and } \\
\text { filtrate taken in empty stomach } \\
\text { Full of a coffee cup daily for } 3 \\
\text { consecutive days }\end{array}$ & oral & Human & [55] \\
\hline 53. & JasminumabyssinicumHochst & Oleaceae & Tembelel $[\mathrm{A}]$ & $\begin{array}{l}\text { Seed } \\
\text { Leaf }\end{array}$ & Not specified & Not stated & Human & [48] \\
\hline 54. & Ximeniaamericana $L$. & Olacaceae & Enkuay[A] & Bark & $\begin{array}{l}\text { Soaking bark in water and the } \\
\text { water is taken orally }\end{array}$ & Oral & Human & [31] \\
\hline
\end{tabular}


Citation: Meresa A, Degu S, Tadele A, Geleta B, Moges H, et al. (2017) Medicinal Plants Used for the Management of Rabies in Ethiopia - A Review. Med Chem (Los Angeles) 7: 795-806. doi: 10.4172/2161-0444.1000431

\begin{tabular}{|c|c|c|c|c|c|c|c|c|}
\hline 55. & Rhoicissus tridentate & Vitaceae Lalo & Lalo[A] & $\begin{array}{l}\text { Root } \\
\text { Leaf }\end{array}$ & $\begin{array}{l}\text { The root and leaf of this plant is } \\
\text { ground together, mixed with water } \\
\text { then } 1-2 \text { water glasses is drunk } \\
\text { for human and } 1 \text { litter is given to } \\
\text { cattle for } 3 \text { day }\end{array}$ & Oral & Both & [28] \\
\hline 56. & $\begin{array}{l}\text { Ajuga alba (Gurke) } \\
\text { Robyni }\end{array}$ & Lamiaceae & $\begin{array}{l}\text { Anamuro } \\
\text { [O] }\end{array}$ & $\begin{array}{l}\text { Leaf } \\
\text { Fresh or } \\
\text { dried }\end{array}$ & Pounded, mixed with water & Oral & Human & [44] \\
\hline 57. & $\begin{array}{l}\text { Flueggeavirosa(Roxb. } \\
\text { ex Willd.) Royle }\end{array}$ & [Euphorbiaceae & Harmazo & Root & Not specified & Not specified & Human & [41] \\
\hline 58. & $\begin{array}{l}\text { AnthemistigreensisJ. } \\
\text { Gay ex A.Rich. }\end{array}$ & Asteraceae & Sifay & $\begin{array}{l}\text { Root } \\
\text { Fresh }\end{array}$ & $\begin{array}{l}\text { Concocted, crushed, mixed with } \\
\text { water } \\
\text { Or Boil and drink the decoction } \\
\text { when cool }\end{array}$ & Oral & Human & {$[44,58]$} \\
\hline 59. & $\begin{array}{l}\text { Asparagus setassus } \\
\text { (Kunth) Jessap }\end{array}$ & Asparagaceae & Zeriti & $\begin{array}{l}\text { Root } \\
\text { Fresh }\end{array}$ & $\begin{array}{l}\text { Concocted, crushed, mixed with } \\
\text { water }\end{array}$ & Oral & Human & [44] \\
\hline 60. & $\begin{array}{l}\text { Convolvulus } \\
\text { kilimandschari Engl. }\end{array}$ & Convolvulaceae & $\begin{array}{l}\text { AserkushTebetebkush } \\
\text { [A] }\end{array}$ & $\begin{array}{l}\text { Root } \\
\text { Fresh }\end{array}$ & $\begin{array}{l}\text { Concocted, pounded, mixed with } \\
\text { water, shaked, filtered }\end{array}$ & Oral & Human & [44] \\
\hline 61. & Zingiberofficinale & Zingebiraceae & Jinjibila [O] & Root & Root concoction is drunk (Rabies) & Oral & Human & [22] \\
\hline 62. & $\begin{array}{l}\text { Asparagus } \\
\text { leptocladodiusChiov. }\end{array}$ & Asparagaceae & Seriti[O] & Root & Not specified & & human & [29] \\
\hline 63. & $\begin{array}{l}\text { Cucumisdipsaceus } \\
\text { Ehrenb. } \\
\text { ex Spach }\end{array}$ & Cucurbitaceae & $\begin{array}{l}\text { Kurera } \\
{[\mathrm{O}]}\end{array}$ & Fruit & Not specified & & human & [29] \\
\hline 64. & $\begin{array}{l}\text { Garcinia livingstonei } \\
\text { T. Anders }\end{array}$ & Clusiaceae & $\begin{array}{l}\text { Abuqurto } \\
{[\mathrm{O}]}\end{array}$ & Root & Not specified & & human & [29] \\
\hline 65. & $\begin{array}{l}\text { Senna } \\
\text { petersiana(Bolle) } \\
\text { Lock }\end{array}$ & Fabaceae & Sanaa maki [O] & Leaf & $\begin{array}{l}\text { Squeezed and given with food } \\
\text { to cattle } \\
\text { Squeezed and } 1 / 2 \text { coffee cup is } \\
\text { given for } \\
2-3 \text { days }\end{array}$ & Oral & Human & {$[20]$} \\
\hline 66. & $\begin{array}{l}\text { Solanumdasyphyllum } \\
\text { Schumach. }\end{array}$ & Solanaceae & $\begin{array}{l}\text { Hidi } \\
\text { waraabesaa[O] }\end{array}$ & $\begin{array}{l}\text { Leaf } \\
\text { Seed }\end{array}$ & $\begin{array}{l}\text { Squeezed and } 1 / 2 \text { coffee cup is } \\
\text { given to the animal }\end{array}$ & Oral & Human & {$[20]$} \\
\hline 67. & PennisetumthunbergiiKunth & Poaceae & $\begin{array}{l}\text { Marga } \\
\text { abaaboo[O] }\end{array}$ & $\begin{array}{l}\text { Leaf } \\
\text { Seed }\end{array}$ & $\begin{array}{l}\text { Crushed, dried, powdered, mixed } \\
\text { with } \\
\text { milk ('Aguat') } 2 \text { spoon is given }\end{array}$ & Oral & Human & [20] \\
\hline 68. & MaesalanceolataForssk & $=$ Myrsinaceae & Abayi[O] & & Crushed, squeezed and taken & Oral & Human & {$[20]$} \\
\hline 69. & Ozoroa insignis Del & Anacardiaceae & Gerri [O] & $\begin{array}{l}\text { Bark } \\
\text { Root } \\
{[\mathrm{L}]}\end{array}$ & $\begin{array}{l}\text { Dried bark and root of the plant } \\
\text { is pounded then } 2 \text { teaspoonful } \\
\text { powder added to } 1 \text { cup of water, } \\
\text { administered orally for } 20 \text { days, } 2 \\
\text { days interval }\end{array}$ & Oral & Human & {$[45]$} \\
\hline
\end{tabular}


Citation: Meresa A, Degu S, Tadele A, Geleta B, Moges H, et al. (2017) Medicinal Plants Used for the Management of Rabies in Ethiopia - A Review. Med Chem (Los Angeles) 7: 795-806. doi: 10.4172/2161-0444.1000431

\begin{tabular}{|c|c|c|c|c|c|c|c|c|}
\hline 70. & Rhustenuinervis & & & Root & $\begin{array}{l}\text { The bark of the root is crushed } \\
\text { and mixed water and the } \\
\text { decoction of the root is drunk after } \\
\text { one hour. }\end{array}$ & Oral & human & [56] \\
\hline 71. & $\begin{array}{l}\text { Afrocarpusalcatus } \\
\text { (Thunb.) C. N. }\end{array}$ & & & & Not stated & & Rabies & [42] \\
\hline 72. & $\begin{array}{l}\text { Rumex nervosas } \\
\text { vani Senna } \\
\text { oteryRicinuscommunis }\end{array}$ & & & Leaves & $\begin{array}{l}\text { Fresh leaves are pounded and } \\
\text { juice is prepared and taken }\end{array}$ & Oral & both & [21] \\
\hline 73. & $\begin{array}{l}\text { Cucumisdipsaleus[ } \\
\text { livestock }\end{array}$ & Cucurbitaceae & Haragoge & Fruit & $\begin{array}{l}\text { The fresh fruit sare crushed } \\
\text { and mixed with the leaf of } \\
\text { cucumisdipsaleus then creamed } \\
\text { on the bitten body and drenching }\end{array}$ & $\begin{array}{l}\text { Dermal and } \\
\text { Orally }\end{array}$ & Livestock & [57] \\
\hline 74. & Ekebergiacapensissparm & Meliaceae & Mukaraso [AM] & Root & $\begin{array}{l}\text { The fresh root are decoction and } \\
\text { mixed with sheep/goat milk then } \\
\text { rubbed on bitten body }\end{array}$ & Oral and dermal & Livestock & {$[57]$} \\
\hline 75. & $\begin{array}{l}\text { Apodytesdimidiata E. } \\
\text { Mey. ex Arn }\end{array}$ & Icacinaceae & $\begin{array}{l}\text { Yetemenjalnchet/ } \\
\text { Donga }\end{array}$ & $\begin{array}{l}\text { Stem } \\
\text { bark }\end{array}$ & Not specified & Oral & Livestock & [59] \\
\hline 76. & Plantagolanceolata L. & Plantaginaceae & Wushamilastinishu & Root & Not specified & Oral & live stock & [59] \\
\hline 77. & PlantagopalmataHook.f. & Plantaginaceae & Wushamilastiliku & Root & Not specified & Oral & live stock & [59] \\
\hline 78. & $\begin{array}{l}\text { Plectranthus lactiflorus } \\
\text { (Vatke) Agnew }\end{array}$ & Lamiaceae & Ayderkush[AM] & Leaf & $\begin{array}{l}\text { Fresh or dried leaves of } \\
\text { Plectranthus lactiflorus, drink the } \\
\text { decoction. }\end{array}$ & Oral & human & {$[58,59]$} \\
\hline 79. & SolanummarginatumL.f. & Solanaceae & $\begin{array}{l}\text { Imbuay } \\
{[\mathrm{AM}]}\end{array}$ & Root & $\begin{array}{l}\text { Crush, heat/ burn or boil the part } \\
\text { and inhale its smoke or steam }\end{array}$ & Oral & Human & [58] \\
\hline 80. & $\begin{array}{l}\text { Cayluseaabyssinica } \\
\text { (fresen.) Fisch. \&Mey }\end{array}$ & Recedaceae & Giesilla [M] & & $\begin{array}{l}\text { Root chopped and mixed with } \\
\text { cold water and } \\
\text { Drenched. (effective even when } \\
\text { clinical signs are present }\end{array}$ & Oral & Both & {$[60]$} \\
\hline
\end{tabular}

Table 2: List of anti-rabies medicinal plants.

$[\mathrm{M}]=$ Maale; $\mathrm{AM}=$ Amharic; $[\mathrm{T}]=$ Tigirigna; $\mathrm{Km}=$ kambatgna; $[\mathrm{O}]=$ Oromigna

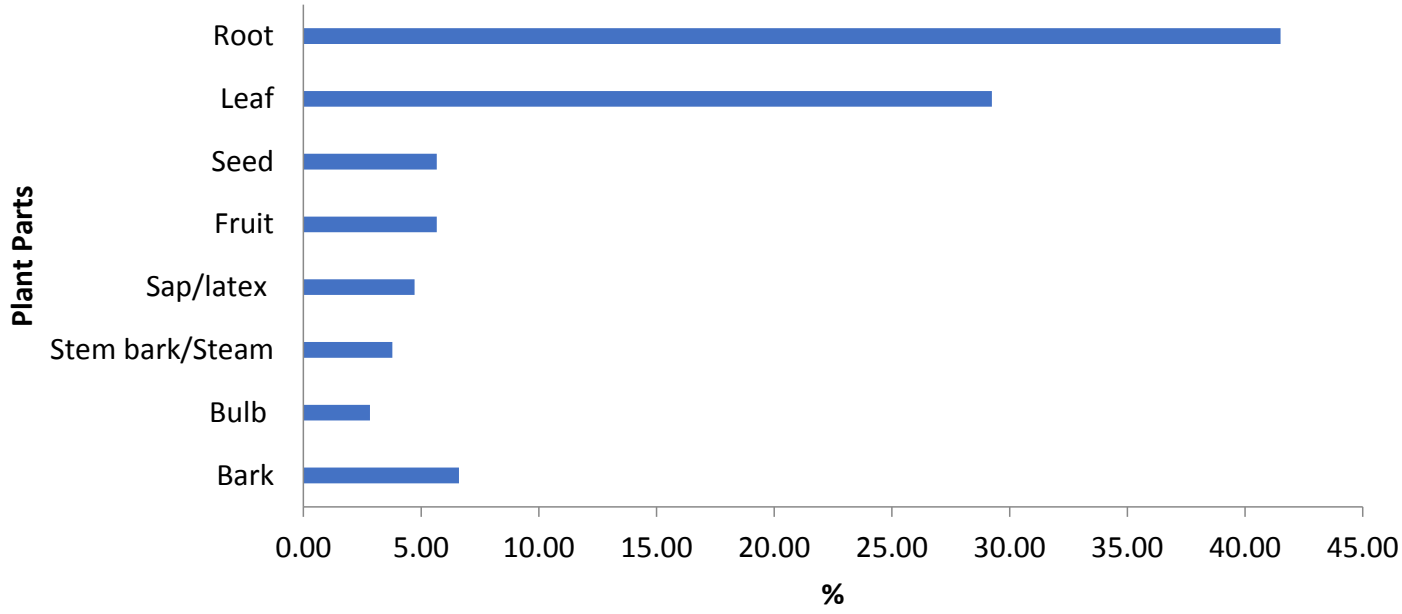

Figure 3: Use of different plant parts for the treatment of rabies in Ethiopia.

Traditional uses: Traditional tooth brush, live fence [62]. Roots are used in medicines that help cure stomach pains, fever, and headaches [64].

Anti-rabies activity or efficacy data: The chloroform, methanol $80 \%$ and aqueous leaf extracts of Salix Subserrata were prepared using maceration technique. Salix subserrata Chloroform crude extract on 1 day and 3 days treatment groups with the chloroform extract are significantly associated with the survival time [12].

Phytochemistry: Flavonoids such as rutin, luteolin-7-glucoside, quercetrin, and quercetin have been isolated from S. subserrata [65]. 


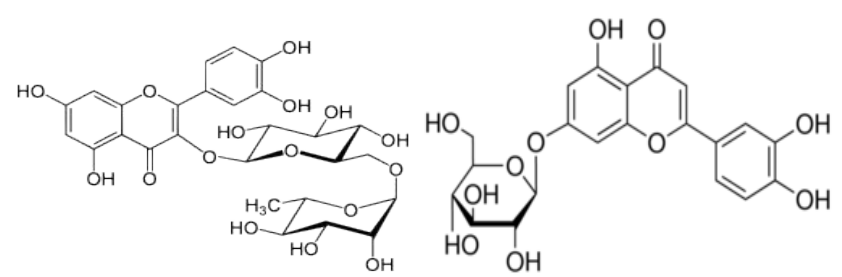

Rutin<smiles>CC1OC(Oc2cc(O)cc(O)c2)C(O)C1O</smiles>

Quercetrin

Quercetin

The bio-guided study of the chemical constituents of the bark and leaves of Salix subserrata (Salicaceae) has resulted in the isolation and characterization of eight compounds. These six compounds were identified as $(+)$ catechin (1), 1,2-benzenedicarboxylic acid, bis (2-ethylhexyl) ester (2), saligenin (3), methyl 1-hydroxy-6oxocyclohex-2-enecarboxylate (4), catechol (5), propyl acetate (6), $\beta$ - sitosterol (7), and $\beta$-sitosterol glucopyranoside (8), were isolated for the first time from Salix subserrata. The above compounds were individually identified by spectroscopic analyses and comparisons with reported data [63] (Figure 4).

\section{Silene macroselen}

\section{Family: Caryophyllaceae}

\section{Local name: Wogert}

Traditional uses: Besides used for rabies management, in Ethiopia, the aqueous infusion of the stem and bark of this medicinal plant is used to treat hypertension, common cold, measles, abdominal pain, and chancroid as well as evil spirits as smoke [66]. Root decoction is also given orally three times a day to treat common cold, headache and fever. Smoke inside the house to drive back snake [67]

Anti-rabies activity [efficacy data]: Another study by Deressa et al. [12] also revealed chloroform and $80 \%$ methanolic root extracts of Silene macroselen were found to increase the survival time of mice significantly [12].

Phytochemistry: No phytochemical screening studies had ever been carried out on the various parts of this medicinal plant.

Safety data: There were no scientific reported data regarding the safety study of this medicinal plant.

\section{Phytolaca decandra}

Family: Phytolaccaceae

Local name: Endod(Amharic)

Traditional uses: Common medicinal uses of berries of this plant include treatment of skin itching (ringworm), malaria, sore throat, rheumatic pain abortion, jaundice gonorrhea, leeches, intestinal worms, anthrax and rabies and for preparation of soaps and detergents $[68,69]$.<smiles>Oc1cc(O)c2c(c1)O[C@H](c1ccc(O)c(O)c1)[C@H](O)C2</smiles><smiles>CCCCC(CC)COC(=O)c1ccccc1C(=O)OCC(CC)(CC)CCCC</smiles><smiles>OCc1ccccc1O</smiles>

3<smiles>COC(=O)C1(O)C=CCCC1=O</smiles>

4<smiles>Oc1ccccc1O</smiles>

5<smiles>CCCOC(C)=O</smiles>

6<smiles>CCC(CC[C@H](C)C1CCC2C3CC=C4CC(O)CC[C@]4(C)C3CCC21C)C(C)CC[C@@H](C)C(CC)C(C)C</smiles>

Figure 4: Compounds isolated from S. subserrata. 
Anti-rabies activity [efficacy data]: A study conducted on mice to evaluate the anti-rabies activity of hydro-ethanolic extract of roots and leaves of Phytolacca dodecandra revealed that $80 \%$ ethanol macerated extract both plant parts at the doses of $300,600 \mathrm{mg} / \mathrm{kg}$ failed to display an increase in survival period of mice challenged with the rabies virus (CVS-11) compared with negative control. However, the leaf extract at $1000 \mathrm{mg} / \mathrm{kg}$ significantly $(\mathrm{P}>0.05)$ increased the survival period of mice compared to negative controls [61].

Phytochemistry: The Phytochemical screening test carried out on the aqueous indicated the presence of alkaloids, tannins, phenols, steroids, triterpenoids, free amino acids and reducing sugars [61]. Oleanolic acid (OA) is one of bioactive compounds isolated from from ethanolic extract of Phytolacca decandra and has been reported to have anticancer effects [71].

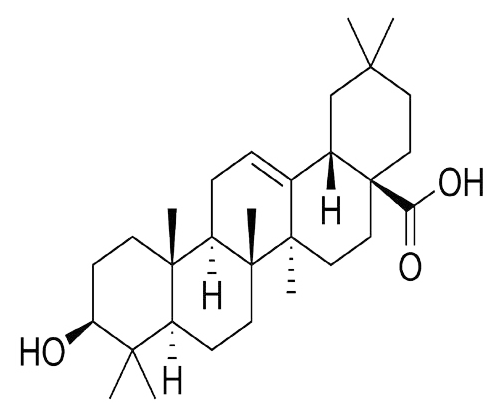

\section{Oleanolic acid (OA)}

Lemma toxin is one of the molluscicidal saponin components isolated from the fruit of Phytolacca dodecandra (endod), a derivative of oleanolic acid substituted in the 3 position with a branched trisaccharide containing two glucose units and one galactose unit [72].

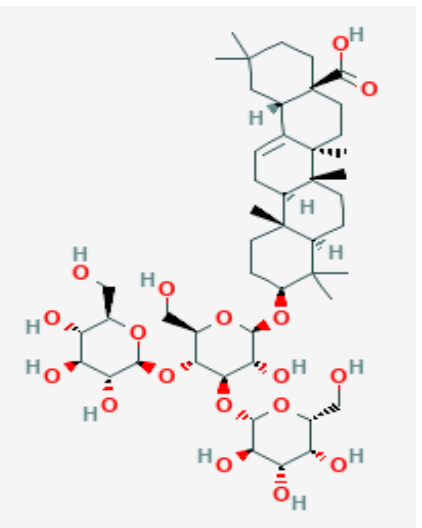

\section{Lemma toxin}

Safety data: A toxicity evaluation study of Phytolacca dodecandra extract for its toxicity effectiveness against aquatic macroinvertebrates clearly indicated that the $\mathrm{LC}_{50}$ and $\mathrm{LC}_{90}$ values for berries crude extract of Phytolacca dodecandra against Baetidae were 181.94 and 525.78 $\mathrm{mg} / \mathrm{l}$ and lethal doses $\left(\mathrm{LC}_{50}\right.$ and $\mathrm{LC}_{90}$ ) required for Hydropsychidae were 1060.69 and $4120.4 \mathrm{mg} / \mathrm{l}$ respectively. This laboratory evaluation demonstrated that Baetidae was more susceptible than Hydropsychidae, even at shorter exposure period of $2 \mathrm{~h} \mathrm{[70].}$

An acute toxicity study revealed that female rats that received the aqueous leaf extract of $P$. dodecandra at the dose of $2048 \mathrm{mg} / \mathrm{kg}$ displayed a reduced appetite, sleepiness and excessive urination and shivering [61].

\section{Conclusion}

In this review study, some of the ethno-botanical claims were confirmed through the in vivo anti-rabies activity studies. This indicates the necessity of documenting ethno botanical indigenous knowledge which contributes for the drug development such as identification of the biologically active compounds, further bioactivity tests, for standardization and formulation development and commercialization and conservation following the indigenous knowledge. Therefore, further research is needed for the evaluation of the safety, efficacy and quality of those medicinal plants utilized for the treatments of rabies in Ethiopia.

\section{References}

1. Admasu P, Mekonnen Y (2014) Rabies and its Folk Drugs Remedies in Ethiopia: A Review. International Journal of Basic and Applied Virology 3: 22-27.

2. World Health Organization (WHO) (2005) Expert Consultation on Rabies: First Report.

3. Reta T, Teshale S, Deresa A, Ali A, Mengistu F, et al. (2014) Rabies in animals and humans in and around Addis Ababa, the capital city of Ethiopia: A retrospective and questionnaire based study. Journal of Veterinary Medicine and Animal Health 6: 178-186.

4. Jemberu WT, Molla W, Almaw G, Alemu S (2013) Incidence of rabies in humans and domestic animals and people's awareness in North Gondar Zone, Ethiopia. PLoS Negl Trop Dis 7: e2216.

5. Ali A (2012) 4.5 National Rabies Baseline Survey Preliminary Report Household Assessment. In The National Workshop on Rabies Prevention and Control in Ethiopia.

6. Deressa A, Ali A, Bayene M, Selassie BN, Yimer E, et al. (2010) The status of rabies in Ethiopia: A retrospective record review. Ethiopian Journal of Health Development 24

7. Ali A, Mengistu F, Hussen K, Getahun G, Deressa A, et al. (2010) Overview of Rabies in and around Addis Ababa, in Animals Examined in EHNRI Zoonoses Laboratory Between, 2003 and 2009. Ethiopian Veterinary Journal 14: 91-101.

8. Deribe K, Meribo K, Gebre T, Hailu A, Ali A, et al. (2012) The burden of neglected tropical diseases in Ethiopia, and opportunities for integrated control and elimination. Parasites \& vectors 5: 1.

9. Pagadala VK, Tsegaye B, Kebede N, Elias T, Gemachu G (2015) Significance of Traditional Medicinal Plants used for Treatment of Rabies at Ambo Town. Medicinal \& Aromatic Plants.

10. Hurisa B, Tegbaru B, Nolkes D, Mengesha A, Kebede G, et al. (2013) Safety and Immunogenicity of ETHIORAB Rabies Vaccine. Journal of Vaccines \& Vaccination 4: 2

11. Lodmell DL, Ewalt LC (2004) Rabies cell culture vaccines reconstituted and stored at $4^{\circ} \mathrm{C}$ for 1 year prior to use protect mice against rabies virus. Vaccine 22: $3237-3239$

12. Deressa A, Hussen K, Abebe D, Gera D (2010) Evaluation of the Efficacy of Crude Extracts of Salix subserrata and Silene macroselen for the treatment of rabies in Ethiopia. Ethiopian Veterinary Journal 14: 1-16.

13. Maryo M, Nemomissa S, Bekele T (2015) An ethnobotanical study of medicina plants of the Kembatta ethnic group in Enset-based agricultural landscape of Kembatta Tembaro (KT) Zone, Southern Ethiopia. Asian Journal of Plant Science and Research 5: 42-61.

14. Wondimu T, Asfaw Z, Kelbessa E (2007) Ethnobotanical study of medicinal plants around 'Dheeraa' town, Arsi Zone, Ethiopia. J Ethnopharmacol 112: 152-161.

15. Tamiru F, Terfa W, Kebede E, Dabessa G, Roy R K, et al. (2013) Ethnoknowledge of plants used in veterinary practices in Dabo Hana District, West Ethiopia Journal of Medicinal plants Research 7: 2960-2971.

16. Amenu E (2007) Use and management of medicinal plants by indigenous people 
of Ejaji area (chelya woreda) west shoa, Ethiopia 2007. An ethnobotanical approach (Doctoral dissertation, Addis Ababa University)

17. Enyew A, Asfaw Z, Kelbessa E, Nagappan R (2014) Ethnobotanical study of traditional medicinal plants in and around Fiche District, central Ethiopia. Current Research Journal of Biological Sciences 6: 154-167.

18. Birhanu T, Abera D (2015) Survey of ethno-veterinary medicinal plants at selected Horro Gudurru Districts, Western Ethiopia. African Journal of Plant Science 9: 185-192.

19. Suleman S, Alemu T (2012) A survey on utilization of ethnomedicinal plants in Nekemte Town, East Wellega (Oromia), Ethiopia. Journal of herbs, spices \& medicinal plants 18: 34-57.

20. Behailu E (2010) Ethno botanical Study of Traditional Medicinal Plants of Goma Wereda, Jima Zone of Oromia Region, Ethiopia (Doctoral dissertation, AAU).

21. Gabriel T, Guji T (2014) Ethnopharmacological Survey Of Medicinal Plants In Agaro District, Jimma Zone, South West Ethiopia. International Journal of Pharmaceutical Sciences and Research 5: 3551.

22. Birhanu T, Abera D, Ejeta E (2015) Ethnobotanical Study of Medicinal Plants in Selected HorroGudurruWoredas, Western Ethiopia. Journal of Biology, Agriculture and Healthcare 5: 83-93.

23. Getnet Z, Chandrodyam S, Masresha G (2016) Studies on traditional medicina plants in Ambagiorgis area of Wogera District, Amhara Regional State, Ethiopia Int. J. Pure App. Biosci 4: 38-45.

24. Chekole G, Asfaw Z, Kelbessa E (2015) Ethnobotanical study of medicinal plants in the environs of Tara-gedam and Amba remnant forests of Libo Kemkem District, northwest Ethiopia. Journal of ethnobiology and ethnomedicine 11: 1.

25. Etana T (2007) Use and conservation of traditional medicinal plants by indigenous people in Gimbi woreda, western Wellega, Ethiopia (Doctoral dissertation, AAU).

26. Abera B (2014) Medicinal plants used in traditional medicine by Oromo people, Ghimbi District, Southwest Ethiopia. Journal of ethnobiology and ethnomedicine 10: 1.

27. Tadesse B, Mulugeta G, Fikadu G, Sultan A, Nekemte E (2014) Survey on Ethno-Veterinary Medicinal Plants in Selected Woredas of East Wollega Zone Western Ethiopia. Journal of Biology, Agriculture and Healthcare 4: 97- 105.

28. Getu A (2016) Ethnobotanical Study on Medicinal Plants used by indigenous Local Communities in Minjar-ShenkoraWereda, North Shewa Zone of Amhara Region, Ethiopia (Doctoral dissertation, AAU).

29. Lulekal E, Kelbessa E, Bekele T, Yineger H (2008) An ethnobotanical study of medicinal plants in Mana Angetu District, southeastern Ethiopia. Journal of ethnobiology and Ethnomedicine 4: 1 .

30. Teklehaymanot T, Giday M (2007) Ethnobotanical study of medicinal plants used by people in Zegie Peninsula, Northwestern Ethiopia. Journal of ethnobiology and Ethnomedicine 3: 1.

31. Teklehaymanot T (2009) Ethnobotanical study of knowledge and medicinal plants use by the people in Dek Island in Ethiopia. J Ethnopharmacol 124 69-78.

32. Giday M, Asfaw Z, Woldu Z (2009) Medicinal plants of the Meinit ethnic group of Ethiopia: an ethnobotanical study. J Ethnopharmacol 124: 513-521.

33. Giday M, Asfaw Z, Woldu Z, Teklehaymanot T (2009) Medicinal plant knowledge of the Bench ethnic group of Ethiopia: an ethnobotanical investigation. Journal of Ethnobiology and Ethnomedicine 5: 1.

34. Abebe M, Haramaya E (2013) Ethnobotanical Study of Traditional Medicinal Plants of Gololcha District, Bale Zone of Oromia Region, Ethiopia.

35. Eskedar A (2011) Ethno botanical study on medicinal plants used by local communities in Debark Wereda, North Gondar Zone, Amhara Regional State, Ethiopia.

36. Eshete MA, Kelbessa E, Dalle G (2016) Ethnobotanical study of medicinal plants in Guji Agro-pastoralists, Blue Hora District of Borana Zone, Oromia Region, Ethiopia. Journal of Medicinal Plants 4: 170-184.

37. Araya S, Abera B, Giday M (2015) Study of plants traditionally used in public and animal health management in Seharti Samre District, Southern Tigray, Ethiopia. Journal of ethnobiology and ethnomedicine 11: 1.
38. Gebeyehu G, Asfaw Z, Eniyew A, Raja N (2014) Ethno botanical study of traditional medicinal plants and their conservation status in Mecha Wereda, West Gojjam zone of Ethiopia. International Journal of Pharmaceuticals and Health care Research 02: 137-154

39. Sintayehu T (2011) An Ethnobotanical study of medicinal plants in Wondo Genet natural forest and adjacent Kebeles, Sidama zone, SNNP region, Ethiopia. Doctoral Dissertation Published by Addis Ababa University.

40. Giday M, Teklehaymanot T, Animut A, Mekonnen Y (2007) Medicinal plants of the Shinasha, Agew-awi and Amhara peoples in northwest Ethiopia. J Ethnopharmacol 110: 516-525.

41. Zenebe G, Zerihun M, Solomon Z (2012) An ethnobotanical study of medicinal plants in Asgede Tsimbila district, Northwestern Tigray, northern Ethiopia. Ethnobotany Research and Applications 10, 305-320.

42. Yineger H, Yewhalaw Y, Teketay D (2008) Ethnomedicinal plant knowledge and practice of the Oromo ethnic group in southwestern Ethiopia. Journal of Ethnobiology and Ethnomedicine 4: 1.

43. Tadesse M, Hunde D, Getachew Y (2005) Survey of medicinal plants used to treat human diseases in Seka Cherkosa, Jimma Zone, Ethiopia. Ethiopian Journal of Health Sciences 15: 89-106.

44. Yineger H, Kelbessa E, Bekele T, Lulekal E (2013) Plants used in traditional management of human ailments at Bale Mountains National Park, Southeastern Ethiopia. Journal of Medicinal Plants Research 2: 132-153.

45. Eshetu GR, Dejene TA, Telila LB, Bekele DF (2015) Ethnoveterinary medicina plants: Preparation and application methods by traditional healers in selected districts of southern Ethiopia. Veterinary world 8: 674

46. Megersa M, Asfaw Z, Kelbessa E, Beyene A, Woldeab B (2013) An ethnobotanical study of medicinal plants in Wayu Tuka District, East Welega Zone of Oromia Regional State, West Ethiopia. J Ethnobiol Ethnomed 9: 68.

47. Haimanot R (2010) An Ethnobotanical Study of Useful Plants of the Farming Site in GozamenWereda, East Gojjam Zone of Amhara Region, Ethiopia (Doctoral dissertation, AAU).

48. Berhan A, Asfaw Z, Kelbessa E (2006) Ethnobotany of plants used as insecticides, repellents and antimalarial agents in Jabitehnan district, West Gojjam. SINET: Ethiopian Journal of Science 29: 87-92.

49. Alemayehu G, Asfaw Z, Kelbessa E (2015) Ethno botanical study of medicina plants used by local communities of Minjar-Shenkora District, North Shewa Zone of Amhara Region, Ethiopia. Journal of Medicinal Plants 3: 01-11.

50. Teklay A, Abera B, Giday M (2013) An ethnobotanical study of medicinal plants used in Kilte Awulaelo District, Tigray Region of Ethiopia. J Ethnobiol Ethnomed 9: 65.

51. Teklay A (2015) Traditional medicinal plants for ethnoveterinary medicine used in KilteAwulaelo District, Tigray Region, Northern Ethiopia. Journal of Biology Agriculture and Healthcare 3: 137-150.

52. Kidane B, van Andel T, van der Maesen LJG, Asfaw Z (2014) Use and management of traditional medicinal plants by Maale and Ari ethnic communities in southern Ethiopia. Journal of ethnobiology and ethnomedicine 10: 1.

53. Yirga G, Teferi M, Kasaye M (2011) Survey of medicinal plants used to treat human ailments in Hawzen district, Northern Ethiopia. International Journal of Biodiversity and Conservation 3: 709-714.

54. Yirga G (2010) Assessment of traditional medicinal plants in Endrta District South-eastern Tigray, Northern Ethiopia. African Journal of Plant Science 4 255-260.

55. Birhanu Z, Endale A, Shewamene Z (2015) An ethnomedicinal investigation of plants used by traditional healers of Gondar town, North-Western Ethiopia. Journal of Medicinal Plants 3: 36-43.

56. Assefa A, Abebe T (2014) Ethnobotanical Study of Wild Medicinal Trees and Shrubs in Benna Tsemay District, Southern Ethiopia. Journal of Science and Development, p: 2

57. Usmane A, Birhanu T, Redwan M, Sado E, Abera D (2016) Survey of ethnoveterinary medicinal plants at selected districts of Harari Regional State Eastern Ethiopia. Ethiopian Veterinary Journal 20: 1-22. 
58. Lulekal E (2014) Plant Diversity and Ethnobotanical Study of Medicinal Plants in Ankober District, North Shewa Zone of Amhara Region, Ethiopia. Doctoral dissertation, Addis Ababa University.

59. Lulekal E, Asfaw Z, Kelbessa E, Van Damme P (2014) Ethnoveterinary plants of Ankober District, North Shewa Zone, Amhara Region, Ethiopia. J Ethnobiol Ethnomed 10: 21.

60. Tolossa K, Debela E, Athanasiadou S, Tolera A, Ganga G, et al. (2013) Ethnomedicinal study of plants used for treatment of human and livestock ailments by traditional healers in South Omo, Southern Ethiopia. Journal of Ethnobiology and Ethnomedicine 9: 1.

61. Admasu P, Deressa A, Mengistu A, Gebrewold G, Feyera T (2014) In vivo Antirabies Activity Evaluation of Hydroethanolic Extract of Roots and Leaves of Phytolacca dodecandra. Global veterinaria 12: 12-18.

62. Mekonnen A (2011) The Role of Homegardens for lin Situ conservation of Agrobiodiversity in Holeta Town, Oromia National Regional state, Ethiopia. Doctoral Dissertation, AAU.

63. Hussain H, Badawy A, Elshazly A, Elsayed A, Krohn K, et al. (2011) Chemical constituents and antimicrobial activity of Salix subserrata. Records of Natural Products 5: 133 .

64. Burkill HM (1995) The useful plants of West Tropical Africa 3: Families JL.

65. Balbaa SI, Khafagy SM, Haggag MY, Sahsah NA (1982) Phytochemical study of certain Salix species cultivated in Egypt. Egyptian journal of pharmaceutical sciences.
66. Kloos H, Menberu T, Tadele A, Chanie T, Debebe Y, et al. (2016) Traditional medicines sold by vendors in Merkato, Addis Ababa: Aspects of their utilization, trade, and changes between 1973 and 2014. The Ethiopian Journal of Health Development (EJHD) 28

67. Ragunathan M, Abay SM (2009) Ethnomedicinal survey of folk drugs used in Bahirdar Zuria District, Northwestern Ethiopia. Indian Journal Of Traditional Knowledge 8: 281-284.

68. Esser KB, Semagn K, Wolde-Yohannes L (2003) Medicinal use and social status of the soap berry endod (Phytolacca dodecandra) in Ethiopia. Journal of Ethnopharmacology 85: 269-277.

69. Tadeg H, Mohammed E, Asres K, Gebre-Mariam T (2005) Antimicrobial activities of some selected traditional Ethiopian medicinal plants used in the treatment of skin disorders. Journal of ethnopharmacology 100: 168-175.

70. Karunamoorthi K, Bishaw D, Mulat T (2008) Laboratory evaluation of Ethiopian local plant Phytolacca dodecandra extract for its toxicity effectiveness against aquatic macroinvertebrates. Eur Rev Med Pharmacol Sci 12: 381-386.

71. Ghosh S, Bishayee K, Khuda-Bukhsh AR (2014) Oleanolic acid isolated from ethanolic extract of Phytolacca decandra induces apoptosis in A375 skin melanoma cells: drug-DNA interaction and signaling cascade. Journal of integrative medicine 12: 102-114.

72. Parkhurst RM, Thomas DW, Skinner WA, Cary LW (1974) Molluscicidal saponins of Phytolacca dodecandra: Lemmatoxin. Canadian Journal of Chemistry 52: 702-705. 